\title{
PROFESSIONAL RISK ASSESSMENT ON THE WORKPLACE OF SURFACE SURVEYOR EMPLOYED IN MEASURING-GEOLOGICAL DEPARTMENT OF COALMINE
}

\author{
Ewa MATUSZEWSKA, Justyna ORWAT \\ Silesian University of Technology
}

\begin{abstract}
:
In this article were shown the identification of threats and the assessment of occupational risk for the surface surveyor by using the Five Steps method and taking into account the health state of workers.
\end{abstract}

Key words: a surface surveyor, identification of threats, occupational risk, the Five Steps method, expanded the Five Steps method

\section{INTRODUCTION}

Surface geodesist who works in the surveing department (surveing-geological) in coalmine has a big influence (also mining surveyor) on proper work of the mining plant [2].

His responsibilities are contained in following law's acts:

- Geological and Mining Law [8],

- Regulation of the Minister of Environment about measuring and geological documentation [4],

- The Movement Plan of mining plant,

- Study of Conditions and Directions of Spatial Development of Municipalities Areas on which coalmine is operating on $[3,7]$,

- Local Plans of Spatial Development of Municipalities Areas, within coalmine is localized [3, 7].

Tasks of surface geodesist are following [1]:

- preparing geodetic situational - altitude measurements of land surface,

- updating basic and situational - altitude maps of land surface about all necessary contents for proper way of working the mine company,

- preparing realization measurements according to the surface facilities and buildings of coalmine,

- preparing inventory and control measurements of constructions and devices placed on land's surface, for example shaft towers, lifting machines, etc.,

- determining limits for safety pillars,

- preparing indicative measurements of the mining underground excavations: situational and altitude,

- preparing prognoses of mining exploitation influences on land surface and buildings those are placed on it,

- preparing project of deformations' measurements caused by the working of underground mining plant,

- making observations of terrain and buildings deformations, there are under effects of mining exploitation,
- making measuring records,

- keeping all measuring records and files in repositories,

- determining structure of surface warp geodesic, localization of measuring points and their way of stabilization,

- determining the datailed method of preparing geodesic measurements according to precision requirements,

- setting measuring points on terrain surface (the most often as the observation lines and the benchmarks on ground) and on buildings (the most often as the benchmarks on walls),

- measurement of groundwaters level (in the wells),

- measurement of water bodies level (in reservoirs and water courses),

- determining with the local municipal government permissible influences of mining exploitation,

- determining exploitation conditions in agreement with local government based on establishments of local land-use plans,

- doing activities related to transfer of measured - geological documentation of closed coalmine to archives in Higher Mining Department.

As far as we can see range of surface geodesist activities is very wide. He is working both in closed space and in the open area. However, more of time he spends on outside work connected to situational - altitude measurements (made for defining range and scope of mining exploitation influences on terrain surface and objects), and also measurements of the level of water in water bodies (from the shoreline of reservoirs or from the surface of water on which the boat floats) and ground waters (through measurement of water level in wells). The variety of professional duties tends to widen the professional risk assessment because of the influence on worker's health. 


\section{IDENTIFICATION OF EQUIPMENT AND THREATS}

Surface geodesist, depends from character of job, usually is carrying in measuring equipment, which total weight is from $9.5 \mathrm{~kg}$ to $14.5 \mathrm{~kg}$.

During situational (linearly - angle) measuring, geodesist uses total station which contains electronic rangefinder (average weight around $4.0 \mathrm{~kg}$ ) or theodolite (weight around $5.0 \mathrm{~kg}$ ) and geodesic tape which length is $50 \mathrm{~m}$ and weight $2.5 \mathrm{~kg}$ (or manual rangefinder - weight around 1.0 $\mathrm{kg})$. Moreover geodesist's equipment contains also wooden tripod weighing approximately $3.0 \mathrm{~kg}$ and shortwave transmitter $(0.5 \mathrm{~kg})$, sketchbook $(0.5 \mathrm{~kg})$ and the color paint (spray $-0.5 \mathrm{~kg}$ ).

Making altitude measurements (leveling) requires from geodesist taking for outside measuring technical leveler: optical or code (weighting $2.5 \mathrm{~kg}$ ) or precise (weight approximately $4.0 \mathrm{~kg}$ ), aluminum tripod (weighting approximately $3.0 \mathrm{~kg}$ ) and two levelling staffs weighting approximately $2.5 \mathrm{~kg}$ (aluminum code staffs) to $6.0 \mathrm{~kg}$ (wooden staffs). Besides all this equipment, geodesist uses radiophone $(0.5 \mathrm{~kg})$, sketchbook $(0.5 \mathrm{~kg})$ and the color paint (spray $-0.5 \mathrm{~kg}$ ).

Work in the terrain for surface geodesist is almost as dangerous as for every random human who is walking on ground. We have to take into account both threats that can cause rather not serious injuries (for example stumbling, falling caused by unseen obstacles or hiden it behind carried equipment), and also threats that have serious effects (hitting through car driving near to place where geodesist is measuring, for example during measuring on the points of observation line stabilized in the roadside).

Moreover, it should be mentioned here about other threats typically connected with the character of work:

- instrument slipping (total station/theodolite/leveler/ distance measuring device) from the tripod head caused by loosening the heart screw, resulting often with hitting the worker's back and legs or even crushing feet,

- slipping levelling staff from the wall benchmark or falling out of hand, that can cause hitting head and other parts of the body or crushing feet,

- breaking geodesic steel, measure tape (roulette) during the distance measurement caused by too strong tightening, that usually causes cut wounds on head, trunk and hand,

- falling into the well as a result of too big tilt towards its bottom (during measurement of groundwater level), results with serious injuries or even death (in case of deep wells),

- falling out from the boat into water body during measurement water level and shape of its bottom (results with hypothermia or drown),

- falling into the shaft tube during the inventory measurements of shaft reinforcement (resulting in death),

- falling out from the shaft tower during the inventory measurement of hoisting machine (resulting in death),

- slipping slope of the coal heap during the inventory measurements of amount extracted raw material, results in partial or complete backfilling geodesist (possible serious injuries or death).

All these risks from above are usually the most common during performing work duties, but in the risk assessment it should be taken into account that all those threats refered to all employees of terrain surface.

\section{GUIDELINES FOR PROFESSIONAL RISK ASSESSMENT}

Professional risk assessment will be done by using two methods - the Five Steps method and expanded the Five Steps method. The expandation is about functions which are including climatic conditions and health of employees [5].

The method of Five Steps to risk assessment is known to be as indicative method, in which the professional risk is described as [6]:

$$
R_{1}=P \cdot S \cdot F \cdot L
$$

where:

$\mathrm{R}_{1}$ - risk,

$\mathrm{P}$ - probability of the event,

$S$ - amount of damage,

$\mathrm{F}$ - exposure,

$\mathrm{L}$ - the number of exposers.

The probability of the event can take values from 0.033 (almost impossible) to 15.0 (certain). The size of damage can be determined from 0.1 (in case of scratches or bruises) to 15.0 (in case of death). Exposure (frequency of exposure) evaluates from 0.5 when the threat appears one time in a year, to 6.0 in case of working in continuous risk. The $L$ parameter has a value from 1.0 in case when one or two person are exposed to risk, to 12.0 when at the same moment is exposed about 16 to 50 people.

This methodology can be not enough in case of some types of workplaces. Therefore, it will be also used the professional risk assessment method proposed by prof. Jan Szlązak and described in paperwork [5]. There were taken into account climatic conditions (function f2) and worker's health (function $\mathrm{f} 3$ ). Using functions from above in equation (1) causes the following modification:

$$
R_{2}=f_{1}(P \cdot S \cdot F \cdot L) \cdot f_{2} \cdot f_{3}
$$

where:

$\mathrm{R}_{2}$ - risk,

$\mathrm{P}$ - probability of the event,

$S$ - amount of damage,

$\mathrm{F}$ - exposure,

$\mathrm{L}-$ the number of exposers,

$f_{1}$ - basic function of the Five Steps method,

$f_{2}$ - function of the climate effect,

$f_{3}$ - function of the influence on worker's health.

Calculated risk index values allow us to locate them to the proper category [6]:

I. from 0 to 5 - the risk is negligible,

II. from 5 to 50 - the risk is low, but important,

III. from 50 to 500 - the risk is high,

IV. more than 500 - the risk is not acceptable.

\section{COMPARISON THE RESULTS OF CALCULATIONS OF PRO- FESSIONAL RISK ASSESSMENT}

The necessary step to make before starting risk assessment is to select random employees who work as a surface geodesist in measuring department (measuring - geological) of coalmine.

There are two workers who took part in the analysis and they are marked with the letters $A$ and $B$. The $A$ worker is 46 years old man, whose work experience in mining industry is 21 years and his health state allows him to continue the job. The B worker is 32 years old man, who started to gain the experience 8 years before. He is perfectly healthy and in very good physical shape. 
In the detailed analysis were following professional threats from identification in chapter 2: instrument slipping (total station/theodolite/leveler/distance measuring device) from the tripod head, slipping levelling staff from the wall benchmark or falling out of hand and breaking geodesic, steel tape (roulette) during measurement of length.

Based on these guidelines for professional risk assessment with using the method of Five Steps was created value of each parameter that together are risk indicator component. For both workers these values are the same because in this method health state and working conditions are not considered. For the threats: instrument slipping (total station/theodolite/leveler/distance measuring device) from the tripod head and slipping levelling staff from the wall benchmark or falling out of hand probability value $(P)$ is defined as 2,0 - possible but unusual; the value of consequences - 2,0 - simple fractures, soft disease; the value of consequences - 2,5 - one time per day; the number of exposed people to 1,0 - one or two person. In case of breaking geodesic, steel tape defined: the probability is 1,5 - unlikely, but it can happen; size of consequences as 2,0 simple fractures, soft disease; frequency of exposure as 2,5 - one time per day and the number of exposed people 1,0 for 1-2 persons.

The fact that the various parameters that create risk indicator for both employees are the same urge us to expand risk assessment about parameters specific for each employee. For this purpose calculations will be modified for the function $\mathrm{f3}$. According to the function of climate effect (f2), it concerns the underground workers, so its value is determined as 1,0 . Taking into account the guidances for expanded Five Steps method [5], for each employee there was assigned the value of health state impact function on risk assessment (f3). For the A worker this function took the value of 7,5 (multiplication of component values: 41-50 years $(2,5)$; working experience $21-30$ years $(2,0)$ and the fact that employee is taking curation to diseases that increase the risk of heart attack $(1,5))$. For the B worker the value of health state impact function was 1,5 (multiplication of component values: $31-40$ years $(1,5)$; working experience $1-10$ years $(1,0)$ and the fact that employee is perfectly healthy and in good physical condition $(1,0))$.
Determination the values of function $f_{1}$ and $f 3$ for both workers allowed for calculating the risk value $R_{1}$ using the formula 1 and the risk value $R_{2}$ using the formula 2 , calculated by expanded method. Summary of professional risk assessment results is presented in the Table 1.

The results from the Five Steps method in all cases showed, that the risk is low, but important. It means that the value is in range from 5 to 50 (it is 7,5 when it was happened breaking geodesic tape to 10,0 for the other events).

The expanded method is showing much more bigger risk values when it is about the $A$ worker, the older one with longer working experience (from 56,3 when breaking geodesic steel tape happen to 10,0 for the other events). Here professional risk increased to high level. In case of the $B$ worker risk value increased according to calculated results from the classic Five Steps method (from 7,5 to 11,3 when breaking geodesic steel tape happen and from 10,0 to 15,0 for the other events), but still it stayed on low, but important level.

The detailed results of an executed professional risk assessment were shown below, for the $A$ employee at the Figure 1 and for the $B$ worker at the picture (Figure 2).

The risk values gained for the $A$ worker and calculated by using the Five Steps method are much more smaller than the risk values calculated by using expanded method. It is caused by value of health state influence function on the value of risk $f 3$, which respectively equals to 0 and 7,5 . Unfortunately, there is necessity to taking special attention to employees with long working experience, because their physical state can be low, and even with high level of the working experience, the professional risk can be high.

The threat of breaking geodesic measure tape had the lowest values of risk indicator. In case of the Five Steps method it was 7,5 and in calculations made by using the expanded method it was 56,3.

The threats of instrument slipping from the tripod head and levelling staff from the wall benchmark had the same results. In case of the Five Steps method risk indicator was 10,0 and in calculations made by using the expanded method it was seven and half times more.

Table 1

Results of professional risk assessment

\begin{tabular}{|c|c|c|c|c|c|c|}
\hline Threat & \multicolumn{2}{|c|}{$\begin{array}{l}\text { Instrument slipping from the } \\
\text { tripod head }\end{array}$} & \multicolumn{2}{|c|}{$\begin{array}{l}\text { Slipping levelling staff from } \\
\text { the wall benchmark }\end{array}$} & \multicolumn{2}{|c|}{$\begin{array}{l}\text { Breaking geodesic, measure } \\
\text { tape }\end{array}$} \\
\hline & Employee & Employee & Employee & Employee & Employee & Employee \\
\hline Parameter & A & B & A & B & A & B \\
\hline P (probability) & 2.0 & 2.0 & 2.0 & 2.0 & 1.5 & 1.5 \\
\hline S (size of demage) & 2.0 & 2.0 & 2.0 & 2.0 & 2.0 & 2.0 \\
\hline F (exposure) & 2.5 & 2.5 & 2.5 & 2.5 & 2.5 & 2.5 \\
\hline $\begin{array}{c}\mathrm{L} \\
\text { (number of exposers) }\end{array}$ & 1.0 & 1.0 & 1.0 & 1.0 & 1.0 & 1.0 \\
\hline $\begin{array}{c}f_{2} \\
\text { (function of climate effect) } \\
f_{3}\end{array}$ & 1.0 & 1.0 & 1.0 & 1.0 & 1.0 & 1.0 \\
\hline $\begin{array}{l}\text { (function of the impact on } \\
\text { worker's healt) }\end{array}$ & 7.5 & 1.5 & 7.5 & 1.5 & 7.5 & 1.5 \\
\hline $\begin{array}{c}\mathbf{R}_{\mathbf{1}} \\
\text { risk - the Five Steps method }\end{array}$ & $\begin{array}{c}10.0 \\
\text { low, but } \\
\text { important }\end{array}$ & $\begin{array}{c}10.0 \\
\text { low, but } \\
\text { important }\end{array}$ & $\begin{array}{c}10.0 \\
\text { low, but } \\
\text { important }\end{array}$ & $\begin{array}{c}10.0 \\
\text { low, but } \\
\text { important }\end{array}$ & $\begin{array}{c}7.5 \\
\text { low, but } \\
\text { important }\end{array}$ & $\begin{array}{c}7.5 \\
\text { low, but } \\
\text { important }\end{array}$ \\
\hline$\frac{\mathbf{R}_{2}}{\text { risk - the expanded method }}$ & $\begin{array}{l}75.0 \\
\text { high }\end{array}$ & $\begin{array}{c}15.0 \\
\text { low, but } \\
\text { important }\end{array}$ & 75.0 & $\begin{array}{c}15.0 \\
\text { low, but } \\
\text { important }\end{array}$ & $\begin{array}{l}56.3 \\
\text { high }\end{array}$ & $\begin{array}{c}11.3 \\
\text { low, but } \\
\text { important }\end{array}$ \\
\hline
\end{tabular}




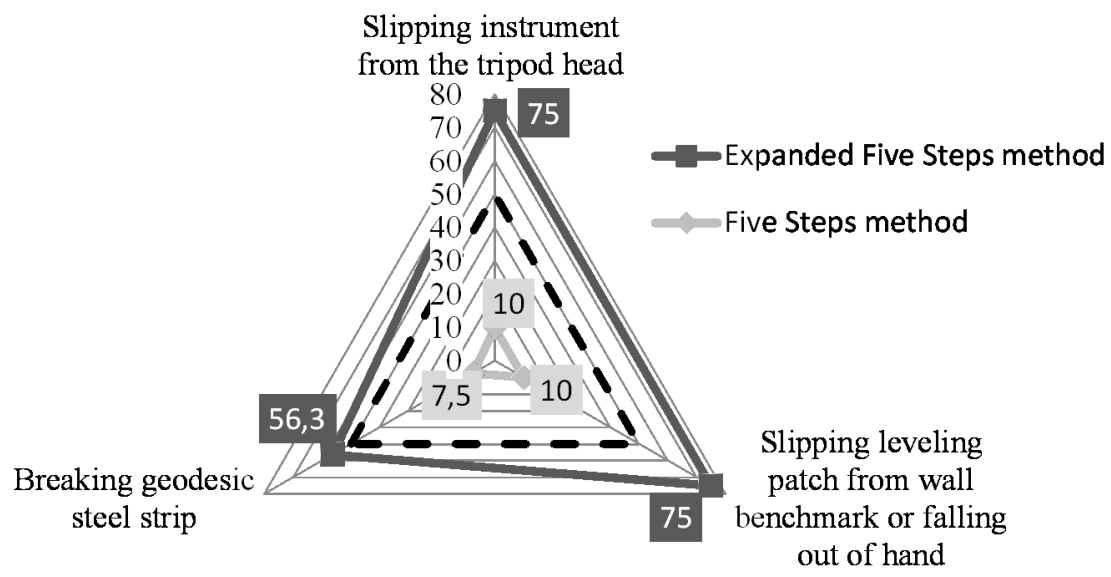

Fig. 1 Summary of the results of professional risk assessment for the A worker

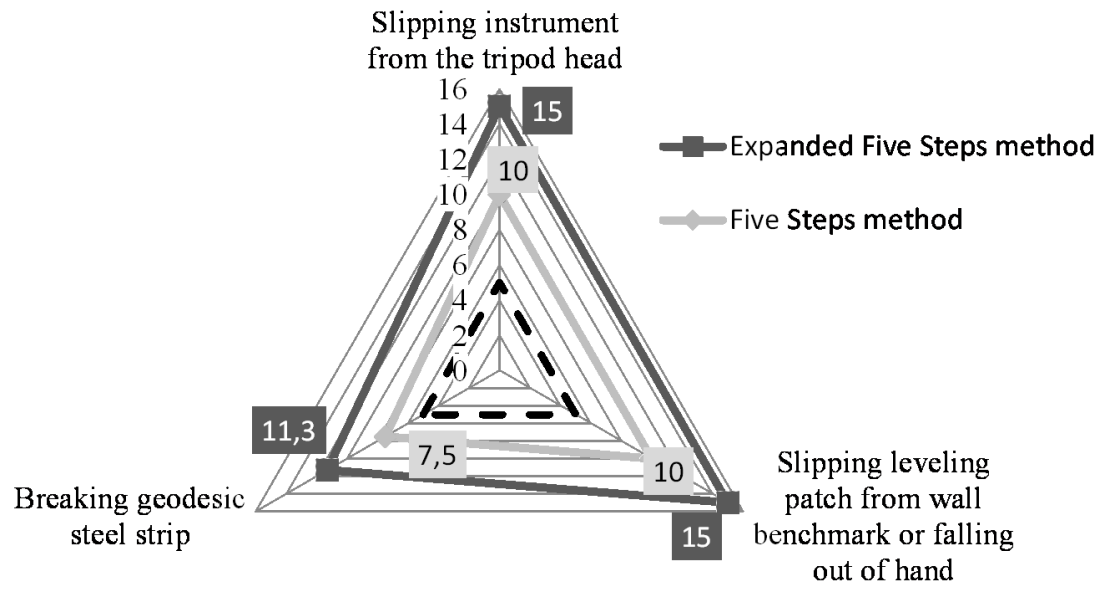

Fig. 2 Summary of the results of professional risk assessment for the B worker

The risk values calculated by using the expanded Five Steps method crossed the limit of high risk what was shown at the Figure 1 by black dotted line. It causes the necessity of starting preventive actions to reduce its level.

The preventive actions that employee can do are following:

- increasing caution during geodetic measurements and generally the same about other activities,

- moving equipment in way that will not cause covering the view for example carring tripod from instrument on the back,

- adjustment of measure tape tension to the needs of measurement and conditions,

- checking an equipment before going for measurements and removing any of its defects or changing an equipment for the other one that is working properly,

- using geodetic tapes made by other materials than steel, which are not springing during stretching,

- turning the instrument to tripod head in correct way with constant control of these two elements,

- using levelling staffs that can be fold and made by lighter material than wood, for example aluminum,

- putting levelling staffs on the middle of the wall benchmarks in very precision way and keeping a constant control of their position during measurements.

The risk values calculated for the B worker by using both methods stayed on level of low but important risk. However, results from the expanded method show that the risk is one and half time higher than the risk calculated by the Five Steps method (in all three situations). The risk indicator reached the lowest value in case of threat defined as breaking geodetic tape $-7,5$ in the Five Steps method and 11,3 in the expanded method. Values of the risk for threats slipping of instrument from the tripod head and levelling staff from the wall benchmark were same in both methods. In case of the Five Steps method risk was on the level 10,0 and in calculations made by using the expanded method it was 15,0.

Generally accepted and well known rule says that we should always try to reduce the risk to minimum. In this case the lines representing level of risk should be tend to the geometric center of the triangle and lie below the black dotted line in Figure 2 which shows the limit of negligible risk.

Reduction of professional risk can be achieved by avoiding and not letting to happen situations which cause an increase of the risk (for example ones that were said in the article). Most of these situations are happening because of lack of worker's attention or his negligence about equipment and his own safety.

\section{FINAL SUMMARY AND CONCLUSIONS}

The surface geodesist position in coalmines is related with many professional threats. Therefore, it is important to describe the risk on this position in proper way and choose the right methods to reduce its level.

In this article, to analyze level of the risk on the surface geodesist position, were choosen three from identified professional threats. Then was made professional risk assessment for two employees named as A and B letter, who are working on the same position, but there are following 
differences between them: age, working experience and state of health. The risk values were calculated by using two methods: the Five Steps method and the expanded Five Steps method.

The results from the Five Steps method for both employees are same, and risk can be defined as low but important. The lowest value of risk indicator was reached in case of threat defined as breaking geodetic, measure tape.

The results from calculating the risk by using the expanded Five Steps method are different than results from the classical method. In case of more experienced employee, but older one - the A worker, risk in all three cases is high. The values of risk indicator for the B worker (younger with shorter experience) stayed in level of low but important risk.

The results from risk assessment show importance of putting attention to employees in aged over 45 and with working experience more than 20 years. Even, if their health remains normal for their age, it can increase professional risk.

The reducing the professional risk level can be achieved by avoiding adverse events that are causing its growth. Most of these events are caused by the geodesist and they are connected to his distraction and lack of proper attention during making the geodetic measurements which should be it given (the human factor). Moreover, the employees before going outside for measuring should carefully check whole equipment and change it or repair it, if they will notice any destructions or abnormalities. Certainly it would partially eliminate the threats caused by defective equipment (the technical factor).

\section{Ewa Matuszewska MSc. Eng, Justyna Orwat MSc. Eng}

Silesian University of Technology, Faculty of Mining and Geology

ul. Akademicka 2A, 44-100 Gliwice, POLAND

e-mail: Ewa.M.Matuszewska@polsl.pl; Justyna.Orwat@polsl.pl

\section{REFERENCES}

[1] Z. Kulczycki and P. Trzcionka. „Geodezja w służbie nadzoru górniczego", in Geodezja, tom 12, z. 2/1, 2006, pp. 267-276.

[2] E. Matuszewska and J. Orwat. „Ocena ryzyka zawodowego na stanowisku mierniczego górniczego wykonującego prace dołowe", in Górnictwo Zrównoważonego Rozwoju 2015, Gliwice, Poland, 2015, pp. 1-11.

[3] J. Orwat. „Planowanie przestrzenne na terenach górniczych w świetle obowiązujących przepisów prawnych", in Górnictwo Zrównoważonego Rozwoju 2015, Gliwice, Poland, 2015, pp. 1-9.

[4] Rozporzqdzenie Ministra Środowiska z dnia 22 grudnia 2011 r. $w$ sprawie dokumentacji mierniczogeologicznej. Dz. U. 2011 nr 291 poz. 1713, 2011.

[5] J. Szlązak. „Wpływ warunków klimatycznych w miejscu pracy i stanu zdrowia pracowników na ocenę ryzyka zawodowego w kopalniach węgla kamiennego", in Zeszyty Naukowe Politechniki Ślq̨skiej (s. Górnictwo i Geologia), tom 8, z. 4, 2013, pp. 89-99.

[6] J. Szlązak and N. Szlązak. Bezpieczeństwo i higiena pracy, Kraków: Wydawnictwo Akademii GórniczoHutniczej, 2010.

[7] Ustawa z dnia 27 marca 2003 r. O planowaniu i zagospodarowaniu przestrzennym. Dz.U. 2003 nr 80 poz. 717, 2003.

[8] Ustawa z dnia 5 marca 2014 r. Prawo geologiczne i górnicze. Dz. U. 2014 poz. 613, 2014. 